\title{
The globalization of intestinal microbiota
}

\author{
D. Raoult
}

Received: 18 May 2010 / Accepted: 23 May 2010 / Published online: 13 June 2010

(C) Springer-Verlag 2010

\begin{abstract}
Many microorganisms reside in human mucosa, specifically in the gut. There are many sources of the microorganisms that colonize our gut, and these sources are mainly environmental. Indeed, food is a major source of bacteria and viruses. Food also modifies the equilibrium of microorganisms in our gut, with vegetables favoring a wider diversity. The increasing role of industrial food in our alimentation is generating a globalization of our gut microbiota that may influence our health and aid the diffusion of clonal bacteria.
\end{abstract}

Humans are complex ecosystems and coexist with an extremely complex invisible population. With an estimated $10^{12}$ prokaryotes (bacteria and archaea) residing in the human body, human bodies contain 100 times more prokaryotic cells than human cells [1], with at least 150 times more prokaryotic genes than human genes [1]. The number of viruses present in the human body is also considerable [2]. Not surprisingly, digestive microbiota have been the subject of many recent studies that raise certain questions about their evolution $[2,3]$.

The role of the digestive microbiota is still largely unknown, but these organisms do contribute enzymes absent in humans for food digestion [4]. Interestingly, many of these enzymes are necessary for the digestion of vegetables. The composition of gut microbiota in animals and humans varies according to the type of food consumed; vegetarian animals and humans have more microbial

D. Raoult $(\bowtie)$

Unité des Rickettsies, UMR CNRS 6236-IRD 198,

Université de la Méditerranée, Faculté de Médecine,

27 Bd. Jean Moulin,

13005 Marseille, France

e-mail: didier.raoult@gmail.com diversity than carnivores and omnivores. This microbial diversity is also associated with higher enzymatic diversity, which is likely necessary for plant digestion.

There exist incontestable links between gut microbiota and obesity, as shown by differences in the ratio between Firmicutes and Bacteroidetes populations in the gut. It is obvious that the manipulation of gut microbiota plays a part in weight gain in animals in which growth promoters (probiotics and antibiotics) have been studied [5]. Gut microbiota from mice with obesity and metabolic syndrome cause obesity when transplanted into normal mice [6]. In humans, preliminary data demonstrate that obese people have more Lactobacillus sp. [7, 8]. Because Lactobacillus is a bacterium often used as a probiotic in animals $[5,9,10]$ and vancomycin, an antibiotic used in the form of Avoparcin as a growth promoter in animals, has a comparable effect in humans, we have tested if it and vancomycin prescribed in association with gentamycin to treat endocarditis is also associated with weight gain [11].

The composition of the intestinal microbiota plays a role in metabolism and, likely, in human health. The source of the microorganisms in the digestive tract has greatly changed in recent years. Historically, the microbial ecosystem of the digestive tract was specific for a geographic area, much as the flora and fauna of an ecosystem are geographically distinct. The visible differences of animals and plants in isolated geographical regions are associated with a comparable microbial diversity. For example, currently in Africa, the microbial composition is very different from that described in Europe or America. Globalization involves a mutualization of living beings. The relative homogeneity of the microbial composition of Europeans and Americans reflects this globalization, rather than a transcendent tendency of humans to select the same bacteria worldwide [1]. 
The question being investigated is whether it is important to identify the source of the gut microorganisms. They are ingested with food, drinks, and in the course of physical contact and inter-human relationships. Children are initially colonized by the mother's milk, the contact with the breast, and, subsequently, their fingers [3]. Thereafter, food will upset this ecosystem. Industrial foodstuffs represent an important source of globalization for gut microorganisms that is specific to the current era. For example, fermented dairy products (e.g., yogurt, functional foods, and fermented cheese) can include $10^{8}$ to $10^{10}$ bacteria, primarily Lactobacillus sp. or Bifidobacterium sp. These strains, which are often patented, are then distributed worldwide, resulting in the globalization of digestive bacterial strains.

It should be noted that this globalization of food has been involved in a series of pandemics, such as epidemics of Escherichia coli contamination in chicken products causing urinary infections in humans [12]. Indeed, epidemics that occur in the farm industry have the potential to cause millions of infections via food consumption.

There is a comparable problem with viruses. The source of the new hepatitis virus subtype (hepatitis E) in developed countries seems to be the mutualization of pig livers in sausages, consumed uncooked, which was involved in a true epidemic in Europe. In France, the "figatelli" (i.e., pork liver sausages) are a vector [13]. In addition, the initial work of Forest Rohwer showed that the human digestive tract includes a huge number of plant viruses [2]. Concerning the source of these viruses, we recently found that Tabasco products were contaminated at a very high level with the mild pepper virus. We showed that there is a statistical link between the presence of this virus at high load (in the feces, the virus is alive and cultivable) and clinical signs of fever, pruritis, and abdominal pain [14]. In this work, we showed that industrial products had a higher rate of contamination than local products due to the mutualization of microorganisms. These elements demonstrate that we are experiencing globalization of the microbial population of our digestive tracts due to industrialized products that homogenize the microorganisms which we ingest.

However, it is necessary to understand that globalization is only occurring in those who live in the global village and consume industrial products. Humans, who have marginal contact with this type of evolution, particularly those living in rural areas, present microbial populations that remain specific to their geographic area.

\section{References}

1. Qin J, Li R, Raes J, Arumugam M, Burgdorf KS, Manichanh C, Nielsen T, Pons N, Levenez F, Yamada T, Mende DR, Li J, Xu J, Li S, Li D, Cao J, Wang B, Liang H, Zheng H, Xie Y, Tap J, Lepage $\mathrm{P}$, Bertalan $\mathrm{M}$, Batto JM, Hansen T, Le Paslier D, Linneberg A, Nielsen HB, Pelletier E, Renault P, Sicheritz-Ponten T, Turner K, Zhu H, Yu C, Li S, Jian M, Zhou Y, Li Y, Zhang X, Li S, Qin N, Yang H, Wang J, Brunak S, Doré J, Guarner F, Kristiansen K, Pedersen O, Parkhill J, Weissenbach J, Bork P, Ehrlich SD, Wang J (2010) A human gut microbial gene catalogue established by metagenomic sequencing. Nature 464:59-65

2. Zhang T, Breitbart M, Lee WH, Run JQ, Wei CL, Soh SW, Hibberd ML, Liu ET, Rohwer F, Ruan Y (2006) RNA viral community in human feces: prevalence of plant pathogenic viruses. PLoS Biol 4:e3

3. Palmer C, Bik EM, Digiulio DB, Relman DA, Brown PO (2007) Development of the human infant intestinal microbiota. PLoS Biol 5:e177

4. Ley RE (2010) Obesity and the human microbiome. Curr Opin Gastroenterol 26:5-11

5. Raoult D (2008) Obesity pandemics and the modification of digestive bacterial flora. Eur J Clin Microbiol Infect Dis 27:631-634

6. Vijay-Kumar M, Aitken JD, Carvalho FA, Cullender TC, Mwangi S, Srinivasan S, Sitaraman SV, Knight R, Ley RE, Gewirtz AT (2010) Metabolic syndrome and altered gut microbiota in mice lacking Toll-like receptor 5. Science 328:228-231

7. Armougom F, Henry M, Vialettes B, Raccah D, Raoult D (2009) Monitoring bacterial community of human gut microbiota reveals an increase in Lactobacillus in obese patients and Methanogens in anorexic patients. PLoS ONE 4:e7125

8. Larsen N, Vogensen FK, van den Berg FW, Nielsen DS, Andreasen AS, Pedersen BK, Al-Soud WA, Sørensen SJ, Hansen LH, Jakobsen M (2010) Gut microbiota in human adults with type 2 diabetes differs from non-diabetic adults. PLoS ONE 5:e9085

9. Raoult D (2008) Human microbiome: take-home lesson on growth promoters? Nature 454:690-691

10. Raoult D (2009) Probiotics and obesity: a link? Nat Rev Microbiol 7:616

11. Thuny F, Richet H, Casalta JP, Angelakis E, Habib G, Raoult D (2010) Vancomycin treatment of infective endocarditis is linked with recently acquired obesity. PLoS ONE 5:e9074

12. Vincent C, Boerlin P, Daignault D, Dozois CM, Dutil L, Galanakis C, Reid-Smith RJ, Tellier PP, Tellis PA, Ziebell K, Manges AR (2010) Food reservoir for Escherichia coli causing urinary tract infections. Emerg Infect Dis 16:88-95

13. Colson P, Borentain P, Queyriaux B, Kaba M, Moal V, Gallian P, Heyries L, Raoult D, Gerolami R (2010) Pig liver sausage as a source of hepatitis E virus transmission to humans. J Infect Dis (in press)

14. Colson P, Richet H, Desnues C, Balique F, Moal V, Grob JJ, Berbis P, Lecoq H, Harlé JR, Berland Y, Raoult D (2010) Pepper mild mottle virus, a plant virus associated with specific immune responses, fever, abdominal pains, and pruritus in humans. PLoS ONE 5:e10041 